\title{
O CORPO EM FESTA: NARRATIVAS EM CENA
}

\author{
Gilmar Oliveira da Silva ${ }^{\mathrm{i}}$ \\ Iduina M. Braun Chaves ${ }^{\text {ii }}$ \\ Tania Marta C. Nhary ${ }^{\text {iii }}$
}

\begin{abstract}
Resumo: O objetivo deste trabalho é apresentar a manifestação da dimensão simbólica do corpo nas festas juninas do Colégio Universitário Geraldo Reis, COLUNI/UFF, através das narrativas de dois estudantes da escola. Buscamos mostrar como a integração da dimensão simbólica do corpo à sua dimensão racional se configura como um novo caminho para a recomposição da identidade desse corpo com liberdade e com prazer no espaço escolar e, de certa forma, compreender como são formadas as redes simbólicas que lhe dão sustentação.
\end{abstract}

Palavras-chave: Festa; Corpo; Arte; Narrativa; Dimensão Simbólica.

\section{THE BODY IN PARTY: NARRATIVES IN SCENE}

\begin{abstract}
The objective of this work is to present the manifestation of the symbolic dimension of the body in the June Festivities of the Colégio Universitário Geraldo Reis, COLUNI / UFF, through the narratives of two students of the school. We seek to show how the integration of the symbolic dimension of the body to its rational dimension is configured as a new path for the restoration of the identity of that body with freedom and pleasure in the school space and, in a way, to understand how the symbolic networks are constructed to give them support.
\end{abstract}

Keywords: Party; Body; Art; Narrative; Symbolic Dimension.

\section{Introdução}

A existência é um fio contínuo de sentimentos mais ou menos vivos e difusos, os quais podem mudar e contradizer-se com o passar do tempo e de acordo com as circunstâncias.

(Le Breton, 2009)

É o enxerto que pode transmitir à imaginação formal a riqueza e a densidade das matérias. Obriga a planta selvagem a florescer e dá matéria à flor. Fora de qualquer metáfora, é necessária a união de uma atividade sonhadora e uma 
atividade ideativa para produzir uma obra poética. A arte é natureza enxertada.

(Bachelard, 1998)

As epígrafes são sugestivas e dão o tom da escrita deste texto que (in)corpora a dimensão prosaica e a dimensão poética, numa harmonia que transcende as dicotomias tão evidentes na contemporaneidade, que aprisionadas por uma lógica excludente, separam, dentre outros, sujeito e objeto, natureza e cultura, razão e emoção, pensamento e sentimento, corpo e alma. Bem nesse espírito, reafirmamos que o estado 'poético' pode ser produzido pela dança, pela música, pela literatura, pela poesia, pelas cerimônias, pelas festas. Estas, apresentam uma outra 'razão' de ser e de se viver no mundo - uma razão sensível. Uma comunhão, mesmo, de pensamentos e de sentimentos.

É importante afirmar que, tradicionalmente, a escola mantém os corpos - de professores e de estudantes - sob controle, pois suas práticas metodológicas apontam para o imobilismo e para a rigidez, o que expressa de forma cotidiana, como menciona Santoro (2005), “a manutenção da hierarquia de poder, das relações estáticas, e o corpo e toda sua infinidade de expressões e possibilidades é um sério risco de descontrole de um sistema que se sustenta pelo medo, pela repressão, pela obediência sem questionamentos” (p. 11). O cotidiano da escola era (e é ainda em muitas delas) regido pelo tempo do relógio: hora do lanche, hora do recreio, hora das aulas específicas. Tempo ao qual nosso corpo vai se adaptando, gradativamente, até amoldar-se a ele. Vemos, então, que a escola se organiza em torno de práticas e rituais que direcionam e controlam o corpo e o movimento da criança.

É sabido que a relação do homem com a sua corporeidade é diferente entre as civilizações oriental e ocidental. Como afirma Gonçalves,

Com base nas tradições místicas do pensamento oriental, a experiência do corpo é vista como a chave para a experiência do mundo e para a consciência da totalidade. O conhecimento do mundo baseia-se, nesse sentido, na intuição direta da natureza das coisas, numa relação com o mundo que envolve intensamente o homem como ser corporal e sensível. A civilização ocidental, com suas raízes na antiguidade grega, tem seu cerne na tendência de uma visão dualista do homem, como corpo e como espírito. Seu processo de desenvolvimento, realizado por meio de tensões e oscilações históricas, caracteriza-se por uma valorização progressiva do pensamento racional em detrimento do conhecimento intuitivo, da razão em detrimento do sentimento e do universal em detrimento do particular. (2008, p. 16) 


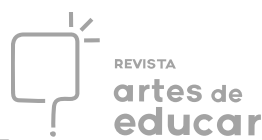

A festa, na sua intimidade com o corpo, revela movimentos vitais e expressões potentes de vivências formativas. A festa junina, objeto de nosso estudo, se afirma na jornada da religação de saberes e afetos na escola, considerando sua dimensão cultural na qual se realizam as práticas simbólicas organizadoras do real social.

É nossa intenção neste trabalho, a partir de fragmentos de uma pesquisa, apresentar a manifestação da dimensão simbólica do corpo nas festas juninas do Colégio Universitário Geraldo Reis, da Universidade Federal Fluminense - COLUNI/UFF, através das narrativas de dois estudantes do Ensino Médio da escola. Dito de outra forma, buscamos mostrar como a integração da dimensão simbólica do corpo à sua dimensão racional se configura como um novo caminho para a recomposição da identidade desse corpo, com liberdade e com prazer no espaço escolar e, de certa forma, compreender como são formadas as redes simbólicas que lhe dão sustentação.

A perspectiva teórico-metodológica se fundamenta na Antropologia da Complexidade de Edgar Morin (2000, 2003, 2011); na Antropologia do Imaginário de Gilbert Durand (1998, 2001); na pesquisa narrativa, com Delory-Momberger (2012), Clandiniy \& Connelly (1990; 2000) e Chaves (2006); nas ideias de corpo com Keleman (2001), Le Breton (2009, 2007), Michel Serres (2004); ludicidade em Huizinga (2004); e Festa com Duviganud (1985), dentre outros.

\section{Ingredientes para temperar a Festa e os movimentos do corpo}

Alimentar-se do paradigma da complexidade é adentrar num solo que pressupõe enxergar, sob a ótica de uma razão sensível, os fenômenos educativos e aceitar que fazemos parte deles e que eles fazem parte de nós. Alimentar-se do paradigma da complexidade é pensar em distinguir as coisas sem isolá-las do todo, é entender que o ser humano precisa ser compreendido de forma multidimensional e complexa em sua inteireza, é também não negar as incertezas, as contradições e as incompletudes da vida. Alimentar-se do paradigma da complexidade é associar razão e emoção, substituir um pensamento que isola e separa por um pensamento que distingue e une, também é compreender que as coisas são simultaneamente concorrentes, antagônicas e complementares e que elas atuam de forma recursiva. Neste sentido, chamamos Morin (2003) para dizer: 
O pensamento complexo não é, porém, uma nova lógica. O pensamento complexo precisa da lógica aristotélica, mas, por sua vez, necessita transgredila (e isso porque ela é igualmente pensamento). Ao ser paradigmaticamente dialógico, o pensamento complexo põe em evidência outros modos de usar a lógica. Sem rejeitar a análise, a disjunção ou a redução (quando for necessária), o pensamento complexo rompe a ditadura do paradigma de simplificação. Pensar de forma complexa torna-se pertinente quando nos defrontamos (quase sempre) com a necessidade de articular, relacionar, contextualizar. (p. 38)

É urgente que haja um projeto de educação que destranque janelas, portas e cortinas, que deixe o sol entrar e abra o coração do/para o mundo. As culturas estão pulsando dentro da escola e clamam por luz, por liberdade, por encontros, por serem postas em evidência no mundo, por uma "reparadigmatização" (Morin, 2011) dos saberes na escola e na vida. O ensino de arte e as ações afirmativas na direção de promover mudanças na dinâmica escolar, tendo a festa como um exemplo, vêm buscando trilhar alguns caminhos para a harmonização e humanização na educação, mas ainda é pouco, precisamos de mais.

Neste sentido, é importante olhar o aluno e a escola através das lentes das diversas dimensões que compõem a condição humana, que se diga: biológica, psíquica, social, afetiva, antropológica, simbólica e cognitiva, através de perspectivas que prezem igualmente pelo lado prosaico e pelo lado poético da vida, que compreendam o homem como um todo em sua complexidade e multidimensionalidade.

Se para alguns o bom da festa é esperar por ela, no COLUNI não há exatamente uma espera, porque a festa começa no dia em que o tema surge, porque é de um mote temático que elas nascem ${ }^{\text {iv }}$. A partir do surgimento das primeiras ideias e devaneios, de pesquisa bibliográfica, dos encontros para elaborar o roteiro e, posteriormente, a confecção de cenários e adereços de figurinos, novas descobertas aconteciam (acontecem) a cada dia e as portas do imaginário iam (vão) se destrancando. Talvez isso nos tenha possibilitado, ao longo dos anos, encontrar um mundo em que foi (é) preciso abstrair o sentido puro da palavra e mergulhar no simbolismo para sorver os muitos significados (COUTO, 2009). Essa era (tem sido) uma forma de ficarmos, assim, prontos para elaborar o roteiro da festa de forma mais racional, induzidos pelo lado afetivo e com muitas incertezas nas mãos, as quais nos instigavam (instigam) e davam (dão) força para continuar. As obras de arte são, também, concebidas assim.

Pensar fazer arte dentro de um paradigma da complexidade é partir de dois pressupostos igualmente importantes: do ponto de vista da ciência das humanidades e do ponto de vista sensível, mas também trazer para junto as questões de ordem técnica científica para poder 
realiza-la, colocá-la em prática e em diálogo recursivo com as questões de ordem socioantropológicas.

Pensar a festa é, sobretudo, pensar nos afetos, nos encontros e também nos desencontros que ela possa acarretar. Por isso foi preciso ter conhecimento técnico para projetar, mas foi preciso uma grande sensibilidade para poder evocar os temas e seduzir a todos para que participassem das encenações, das coreografias ou mesmo para estarem presentes no dia.

A Epistemologia da Complexidade e a compreensão do fenômeno educativo, sobretudo do ensino de arte na escola, levam à reflexão de que a poesia, o amor e a sabedoria são elementos essenciais na condução e na produção dos fazeres artísticos dentro e fora da sala de aula. Além de serem fundantes de novas culturas, sem deixar de lado as já existentes, este modo de pensar e agir possibilita novos rumos para o ensino de arte, porque pressupõe encontros e desencontros que envolvem subjetividades e objetividades, sonhos, devaneios e realidades, razão e emoção, corpo e socialidades ${ }^{\mathrm{v}}$, arte e, sobretudo, a complexa teia que a envolve. Assim, a arte entendida em sua complexidade, sempre foi a grande condutora da festa junina dessa escola em tela. As danças, os textos literários, a teatralidade, a música, a relação com o espaço na perspectiva do teatro, a indumentária e as artes visuais, elementos que compõem a estrutura da festa, carecem destes dois lados do fazer artístico: o prosaico e o poético.

Neste sentido, olhar para a festa numa ótica da complexidade é essencialmente importante e necessário para compreendê-la, é buscar espiar suas múltiplas faces. É importante lembrar que aqui a complexidade não pode ser encarada como receita, mas como um desafio e como uma motivação para pensar sobre as festas e dar a importância devida ao que envolve a humanidade do humano que há no homem, como acentua Morin (2000b):

[...] as atividades de jogo, de festas, de ritos não são apenas pausas antes de retomar a vida prática ou o trabalho; as crenças nos deuses e nas ideias não podem ser reduzidas a ilusões ou superstições: possuem raízes que mergulham nas profundezas antropológicas; referem-se ao ser humano em sua natureza. (p. 59)

E, no ser humano, o desenvolvimento do conhecimento racional-empírico-técnico jamais anulou o conhecimento simbólico, mítico, mágico ou poético.

Falar da festa é como falar de poesia, porque ela mesma (a festa) é uma forma de poesia, já que a poesia é o que nos coloca em estado poético, dessa forma, é imperativo entender que o homem, segundo Morin (2011), é constituído de poesia/prosa e que essa dupla tece a nossa vida. Nas suas palavras, "o estado poético pode ser reproduzido pela dança, pelo canto, pelo culto, pelas cerimônias e, evidentemente, pelo poema" (p. 36). 
Assim, aqui fica Morin esperando novas deixas para entrar em cena. Vamos agora buscar ervas aromáticas no sociólogo Michel Maffesolli.

Olhar para a escola através das lentes da sociologia do cotidiano é estar atento a pensar a partir dessa "razão sensível", permitindo que se traga luz àquilo que está no fundo das aparências. Trata-se de olhar a vida na escola, explodida em flor, buscando compreender a integração entre o saber orgânico-corporal e o saber social, reacendendo aquilo que o racionalismo faz questão de apagar com tinta cinzas-concreto: os afetos, a comunhão, a ligação entre os saberes, o imaginário e o sentimento de pertença.

Nesta direção, o ideário sócio-antropológico de Michel Maffesoli (2011) aponta que a razão já não é a "deusa única que devemos celebrar, mas ela deve aceitar compor o panteão social com outras entidades que veneramos, o corpo, a imaginação onírica, lúdica” (p. 146). Para o autor há uma eficácia existencial e concreta e dada a sua importância não podemos negála. Desta maneira, o autor nos ajuda a entender a escola como forma de integrar e compreender a "mística do estar junto", por uma noção de cultura que pressupõe que nada pode ser compreendido dela caso não se aceite que existe uma espécie de "algo mais", uma ultrapassagem, uma superação da cultura. Esse "algo mais" é, para Maffesoli (2010), a busca da apreensão do imaginário nos espaços instituídos e instituintes.

Maffesoli (2010) afirma que [...] "os momentos festivos não devem ser vistos como sem valor, tais acontecimentos são dotados de um conjunto de emoções coletivas, que demonstram um irreprimível querer viver" (p. 28). Assim, a arte não deve ser reduzida apenas às obras culturais, mas toda a vida cotidiana é uma obra de arte. É, portanto, a partir de uma arte generalizada que se pode compreender a estética como faculdade de sentir em comum. O prazer e o desejo de estar junto, "experimentar junto emoções, participar do mesmo ambiente, comungar dos mesmos valores, perder-se, em teatralidade geral" (ibidem), permitindo que todos esses elementos, que compõem a superfície das coisas e das pessoas, façam sentido, ao que o autor denomina de "ética da estética".

Para Maffesoli (2010), o sentido de estética relaciona-se com o conceito de aisthésis (faculdade de percepção através dos sentidos). Perceber com os sentidos é entrar em uma outra dimensão humana na escola, uma dimensão em que o corpo é aceito em sua totalidade na relação com o outro; perceber, através dos sentidos, o estar junto, vibrar junto, viver em comunhão, partilhar aquilo que afeta a todos. Portanto, a estética maffesoliana está diretamente ligada a uma ética em que viver em comunidade revela sua socialidade baseada nas imagens compartilhadas, que juntas comungam um mesmo gosto de "estar", "viver", "sentir" o mundo, 
um compartilhamento de culturas (Morin, 2000b) e suas múltiplas possibilidades de ser e existir no mundo. Festa, neste sentido, pressupõe também compartilhamento.

$\mathrm{Na}$ busca desenfreada por uma razão que desse conta das descobertas científicas racionalizantes, o homem moderno acabou esquecendo que tem um corpo que sente, que vibra, que sonha, que vive, que devaneia e que tem, sobretudo, alma; um corpo múltiplo em si mesmo, mas que a modernidade perdeu ou escondeu numa câmara escura. Para Maffesoli (2011), estamos em busca deste corpo perdido. As festas, por partirem do princípio do encontro de pessoas, tornam-se um campo fértil para a pesquisa do imaginário de grupos, bem como para captar a cultura nos seus modos de sentir, pensar e agir, o que, para Morin (2000b), é uma dinâmica de complexidade.

Para capturar o quão vibracional estiveram os corpos dos sujeitos do COLUNI no processo de preparação e execução das festas juninas, partimos do pressuposto de que o corpo é a materialização de nossa existência, que, por sua vez, é "um fio contínuo" repleto de modulações. O corpo sofre variações de sentidos (SERRES, 2004) na medida em que vai sendo contagiado pelo mundo apresentado. Essas variações são uma espécie de metamorfose cujo nascedouro é o espírito. Esse envolvimento vai federando sentidos ao corpo e o unindo ao tempo e ao espaço vividos, promovendo assim uma multiplicidade de sensações, como desejos, êxtases, frustações, escapes e tudo o que advém desse estado de transcendência que o corpo vibracional proporciona. Ir além, atravessar fronteiras, ousar, contar com sua própria generosidade para usufruir de um momento único, nunca igual. E foi esse o legado deixado pelas festas juninas dessa escola: uma forte ligação com o sentimento lúdico, qual seja, uma escolha voluntária, vivida em um tempo singular que permite um escape da realidade fazendo dela outra, mas sem, no entanto, um total descolamento da mesma (HUIZINGA, 2004). Por esse entendimento, o corpo foi um forte vetor de diferentes fruições.

No entanto, sabemos que cada corpo é único, assim como sua maneira de dizer-se, mesmo que atravessado por valores, crenças, culturas, normas, regras, interditos e paixões. $\mathrm{O}$ corpo é carne no mundo capaz de se transformar constantemente. Ardilosamente ele se metamorfoseia. Se comunica não somente por palavras, mas por posturas, atitudes, gestos e ações, lhe sendo capaz rearranjar-se o tempo todo, a medida em que as experiências e vivências os suscita.

A intensidade em que nos é permitido vivenciar as frequências vibracionais do corpo depende de onde e como ele se insere, visto que nossa corporeidade é também um fenômeno social e cultural; simbólico e representativo de imaginários. Afirma David Le Breton (2007) que, "pela corporeidade, o homem faz do mundo a extensão de sua experiência; transforma-o Revista Interinstitucional Artes de Educar. Rio de Janeiro, V. 7, N. 1 - pág. 151-170 janeiroabril de 2021: "Pedagogias Vitais: Corpo, Desejo e Educação" DOI: 10.12957/riae.2021.54782 
em tramas familiares e coerentes, disponíveis à ação e permeáveis à compreensão” (p.8). E, sendo o corpo esse lugar de contato privilegiado do indivíduo com o mundo, ele sofre também as interveniências que esse mundo emana e que muitas vezes se deseja, mas não se pode delas escapar. Cumprem então os rituais festivos, esportivos e religiosos, de caráter lúdico, proporcionarem uma via de escape e entrega, ao mesmo tempo sutil e exuberante. São essas modulações que provocam tensões nos espaços institucionalizados, principalmente nas escolas, nosso locus de investigação. Nelas, norma e vida coabitam, ordem e desordem oscilam, objetividade e subjetividade se inserem. Como dar conta de tais tensões necessárias? Como minimizar seus impactos nos humores dos sujeitos da escola? Que Pedagogia nos satisfaz?

Para Duvignaud (1985), a ausência de regras tem mais impacto que a decomposição das normas, mas ao se possibilitar vazar o espontâneo, o sujeito ganha relevo permitindo que o "Eu" se mostre. No caso das festas juninas do COLUNI, as regras garantiam o andamento do evento, e, embora houvesse uma coreografia dançante aqui e ali, elas apenas guiavam a possibilidade de explosão do Eu, um "eu" encarnado no corpo, dado o caráter de como ela, a coreografia, foi sendo concebido ao longo da preparação do evento, momentos em que as possibilidades de movimentos expressivos eram suscitadas pelo professor que "cutucava" o estado de alma do dançante/brincante.

Para Duvignaud, (1985) o poder das festas é uma possibilidade de desprendimento do indivíduo de si próprio para vibrar em comunhão, onde o corpo, mais livre, se volta para sua essência. Uma espécie de transe ${ }^{\mathrm{vi}}$ vital.

Tornar-se outro, identificar-se com um personagem imaginário não é, como se costuma dizer, um ato psicológico; é a revelação ou o encontro de uma evidência que põe em julgamento todo um sistema de cultura e restabelece, por certo período, um diálogo do homem com a natureza que recusamos com todo empenho. (p. 223)

Vale destacar que para esse autor, e a seu tempo de produção da obra mencionada, as festas se classificam em "Festas de Participação" e "Festas de Representação". As primeiras remetem aos rituais públicos, comunitários, com participação consciente do que nelas acontece. A presença de mitos e símbolos normalmente é bem marcada. Já nas Festas de Representações há a participação de "atores" e "espectadores", sendo assim, na visão do autor, menos "destruidoras" por não irromperem com as forças negativas da natureza (Ibidem, p.145), visto que, para Duvignaud, uma festa, para existir, precisa de elementos transgressores e subversivos. Seria um escape para um mundo à parte onde a ausência de regras tem mais impacto do que a decomposição das normas. Essa força destruidora, "coloca o homem frente a um mundo sem 
estrutura e sem código - o mundo da natureza, onde têm exercício apenas as forças do 'Eu', grandes estímulos para a subversão”. (DUVIGNAUD, 1985, p. 68).

Mas foi justamente na comunhão desses dois estilos que as festas juninas do colégio universitário aconteceram. Representação e participação se tornaram evidentes e complementares. Todos se sentiram pertencentes a esse ritual, o que lhes permitiu dançar, cantar, se expressar e se fundir ao todo festivo. As forças de "eu" conduziram a subversão a um processo de experimentação. Novos olhares para os mitos, os ritos, crenças e valores, de modo a despertar a compreensão da identidade de si e do outro, de forma respeitosa. Corpos em festa, cada um a seu modo participando dessa espécie de cortejo contagiante. Norma e vida, para além de ensejos escorregadios que por lá aparecessem, criaram uma ambiência favorável para o corpo vibracional. Assim, por um consentimento tutelado, visto que as festas se filiam à cultura e à cultura da escola, houve uma permissão para a fuga da realidade em direção ao íntimo "eu". Abriu-se um caminho também para a comunhão, para o estar junto, de corpo e alma; para o fazer e o sentir junto-com, nas palavras de Michel Maffesoli , uma "proxemia". Para esse autor, na obra "O Tempo das Tribos: o declínio do socialismo nas sociedades de massa" (2000), a noção de proxemia expressa a história vivida por cada sujeito cotidianamente, no dia a dia, em detrimento da história factual, em que o individualismo se enfraquece frente ao senso comunitário. Vem daí a noção de "tribos", ou seja, filiar-se a um grupo que promova uma vibração em comum.

Voltamos a Le Breton (2009) para destacar a noção de "paixões ordinárias”, que por um viés antropológico, afirma que as nossas percepções sensoriais e a forma como expressamos nossas emoções emanam de nossa intimidade mais secreta, mas que também são modeladas social e culturalmente. Para Breton (2009), o entrelaçamento entre corpo, natureza e cultura lhe confere ao primeiro uma incrustação no campo simbólico, visto que funde razão e emoção (p.5). Foi essa a oportunidade consentida nas festas: procurar e dar relevo aos segredos perdidos, escondidos no corpo e no espírito.

Neste trabalho, na intensão de capturar os simbolismos do imaginário que se circunscreveu nas festas juninas do COLUNI, recorremos à pesquisa narrativa, entendendo, segundo Chaves (1999), que o ato de contar histórias, como um importante processo que, possibilita a reconstrução dos eventos no passado e um meio valioso para entendimento de nossa prática no presente, bem como ilumina sua perspectiva para o futuro. A narrativa contradiz também a dicotomia pensar/sentir (fruto do pensamento moderno ocidental) que liga o conhecimento ao sentimento e o pensamento à ação, ou seja, é potente em fazer emergir a experiência individual, aquilo que é dito mediado pelo sentimento, pela afetividade, pelo que Revista Interinstitucional Artes de Educar. Rio de Janeiro, V. 7, N. 1 - pág. 151-170 janeiroabril de 2021: "Pedagogias Vitais: Corpo, Desejo e Educação" DOI: 10.12957/riae.2021.54782 
nos toca. E mais, quem conta também é testemunha e, portanto, é autor da história narrada. História que contempla, de forma pessoal/coletiva, os aspectos vividos no cotidiano.

Clandinin \& Connelly $(1990 ; 2000)$ consideram a pesquisa narrativa como uma forma de compreender a experiência, como uma forma dos sujeitos experimentarem a vida, como nos relacionamos com os outros e com o mundo que nos cerca.

Christine Delory-Momberger (2012), entende a narrativa como uma ciência que

[...] alimentada por uma ampla tradição hermenêutica (Dilthey, Gadamer, Ricœur) e fenomenológica (Berger, Luckmann, Schapo, Schütz), a pesquisa biográfica estabelece uma reflexão sobre o agir e o pensar humanos, mediante figuras orientadas e articuladas no tempo que organizam e constroem a experiência segundo a lógica de uma razão narrativa. (p. 524525 , grifos da autora)

Enfim, o termo Narrativa, no Dicionário de termos Literários, seu autor, Harry Shaw (1982), faz equivaler narrativa a narração, que deriva de uma palavra latina que significa “contar". Para ele a narração é uma forma de discussão cujo objetivo principal é o de relatar um evento ou uma sucessão de eventos. Nesta direção e neste texto, a Festa será contada por dois estudantes, que em corpo e alma, as viveram intensamente.

Imersos na busca por caminhos, necessariamente ousados, que nos levem à rupturas das velhas práticas educativas, nós, professores/pesquisadores, precisamos nos voltar e ouvir novos e outros dizeres, sobretudo os do corpo. Devemos, como bem anunciou Morin (2000a), "resistir àquilo que nos separa, desintegra e distancia” (p.274). Necessitamos, devagar e urgentemente, repensar a escola por um viés mais sensível, mais lúdico, mais prazeroso, mais poético. E foram eles, os dançantes/brincantes que nos revelaram isso.

\section{Os dizeres dos corpos em festa: Bastiana Africana em sonho de capulana}

De turbante entrelaçado na cabeça e uniforme no corpo, lá vem Bastiana Africana pensando na festa, pisando leve o chão. É uma linda menina negra de olhos grandes expressivos, sorriso solto, batom encarnado nos lábios e andar que desliza pelos corredores da escola. Sua história começa no COLUNI quando era ainda muito pequena. Tinha sete anos de idade e, hoje, com 15, é aluna do primeiro ano do Ensino Médio. Admira muito as festas juninas dessa escola por apresentarem temas e narrativas diferentes a cada ano, mas relatou que sempre ficou ansiosa todas as vezes em que participou, pois sempre estava preocupada se sua família compareceria 
ou não para vê-la em cena. Disse que esse sentimento também "perturba os colegas". O que vestir na festa sempre foi importante para Bastiana Africana, porque entende que a roupa traz em si a identidade de quem veste, por isso, além de ter que estar de acordo com a proposta da apresentação, é necessário também que a roupa diga quem é a pessoa vestida.

Bastiana Africana disse andar ultimamente muito atenta para as questões de identidade, por esse motivo compareceu à entrevista para a pesquisa usando turbante na cabeça. Naquela semana, havia sido comemorado o dia da consciência negra no Brasil e, como militante da causa, resolveu vir de cabeça adornada em tecido entrelaçado, lembrando capulana ${ }^{\text {vii }}$. Isso para ela é muito importante. No entendimento dela, a festa junina, no geral, é o lugar em que as pessoas reúnem-se para “curtir” outras culturas, “mas no colégio isso vem sendo potencializado durantes os últimos anos nos festejos de junho, porque ali não somente se curte, mas se vive a cultura de diferentes lugares e diferentes pessoas. Isto é muito bom”. Contou que, ao longo de sua história no Geraldo Reis, participou de poucas festas juninas. Chegou muito pequena à escola e suas interações sempre foram tímidas, mas lembrou que, antes de 2011, a estrutura das festas era diferente de como ocorre em dias atuais. Rememorou que na festa que recebeu o título de COMO NASCE UM CABRA DA PESTE, achou muito bom participar junto a sua turma, embora não tenha em memória nitidamente o que aconteceu, mas lembra de que olhava aquilo e achava tudo muito bonito e bom de se fazer. Estava no quarto ano do Ensino Fundamental.

Sua lembrança mais nítida a levou para 2012, a partir da festa intitulada MAMULENGO LENGO TENGO. Lembrou-se dos alunos do Ensino Médio dançando com os alunos do primeiro ano do Ensino Fundamental, isto parecia impossível, porque os alunos maiores jamais se misturariam com os pequenos, aquilo causou surpresa, como revela:

A gente ficou muito surpreso quando se misturou as turmas na dança do mamulengo, e esta dança foi muito legal porque as turmas estavam misturadas, o terceiro ano com os pequenininhos, os grandes segurando os pequenos. Foi muito legal porque quando a gente é pequenininho, a gente admira muito o Ensino Médio, e ver os dois juntos ali foi demais, ficamos muito emocionados com aquela mistura. Esse encontro, do Ensino Médio com os pequenininhos é a troca de experiência, uma relação que a gente nunca teve no cotidiano. (Fragmento da narrativa de Bastiana Africana)

Bastiana Africana afirmou que os encontros promovidos nas festas juninas ajudam a construir a identidade da própria escola e também contribui para uma boa imagem da escola mediante as famílias e convidados que participam da festa, fator importante e necessário para a autoestima de toda a comunidade, como mencionado por ela. "Ao retornarem para suas casas, todos saem impressionadíssimos com a festa junina. E isso é muito importante para o 
COLUNI, porque mostra que se a gente quiser a gente pode fazer". Segundo ela, as festas juninas mostram quem são, verdadeiramente, os alunos dessa escola. Isso é, para ela, como uma grande revelação. $\mathrm{O}$ fato de todos entrarem em cena para dançar juntos, corpos e corações, despertou em Bastiana Africana sensações pouco experimentadas em sua vida. Quando dança nas festas, sente-se libertando-se do mundo e diz que várias vezes viu seus colegas transformarem-se em cena, como conta: "você chega para uma pessoa conhecida e a vê dançando como se fosse outra pessoa. E desconhece aquele estado que os colegas apresentam, porque o cotidiano não te deixa perceber a pessoa com aquela sensação”. Para ela, isso é impressionante.

Para Bastiana Africana, os temas das festas foram muito importantes. Na sua leitura, eles tiveram, em sua maioria, questões relacionadas às identidades, identidade cultural, identidade de gênero, de raça, de religiosidades, etc. Afirmou que, talvez, essa seja uma das melhores formas de se trazer debates para a escola e, por esse motivo, disse entender a festa como um grito de manifestação artística, como relata em suas palavras as seguir:

[...] daí quando se abrem os estudos para a festa, a gente tem que procurar, que estudar, que entender melhor e isso vem nas aulas de Artes, que têm sempre essa coisa do estudo de outros lugares que a gente acaba não tendo muito acesso, por não querer as vezes ou até mesmo por preconceito. Isso desperta na gente a seguinte pergunta: como eu vou dizer que as coisas do Nordeste não são tão boas como as do Sudeste se eu não sei? Então, a partir do momento em que apresentamos e estudamos a gente já pode ter uma ideia do que seria, do que eu acho, do que posso defender. Então, essas manifestações artísticas afetam os alunos, envolvem a identificação deles, pois olhe, eu sou do Sudeste, mas me identifiquei muito com essa cultura, vou procurar saber.

E é isso, é abrir os olhos para novas coisas. $\mathrm{Na}$ festa isso é visto pelas pessoas, e ficam surpresas em perceber que discutimos sobre gênero, sobre amor.... que não somente português e matemática.

Ela foi a protagonista da festa intitulada AMOR ANTONIX AMOR, quando fez o papel de Antonieta. Interpretar essa personagem possibilitou-lhe um dos momentos mais importantes que passou na escola, porque não acreditava e não sabia que o colégio confiava tanto nela e, por isso, deu-lhe uma tarefa tão importante. Disse que jamais vai esquecer aqueles momentos mágicos, do processo e do aprendizado que adquiriu ao longo dos ensaios e da apresentação. Sua alegria em participar da entrevista foi contagiante porque, enquanto contava, dizia estar sentindo um pouco do que sentiu durante as festas. Por isso não quis contar somente uma experiência de vida, mas também confidenciar o processo de construção de sua identidade que 


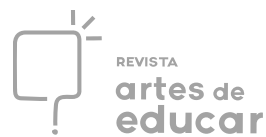

estava fervilhando dentro do seu coração naquele momento e disse que falar sobre as festas foi muito bom, porque a fez lembrar de muita coisa boa. Bastiana agradeceu a oportunidade de poder fazer uma reflexão e perceber como o festejo de junho tem forte influência no que se diz ser o COLUNI. Não foi à toa que a imagem escolhida por ela para representar a festa junina dessa escola diz respeito a uma identidade nublada, ou o caminho de se chegar até uma identidade. Isso está presente nos caminhos curvos do turbante envolto às suas madeixas, à sua atitude diante do interesse em participar dessa entrevista e da força com que encarou o personagem: Antonieta na festa Amor, AntoniX Amor. E em sua fala: "Então estas manifestações artísticas afetam os alunos, envolvem a identificação deles. "

As imagens de Bastiana reveladas em pinturas ${ }^{\text {viii }}$ e palavras nos mostram uma menina que se encontra em labirinto esfumaçado. O que nos remete aos simbolismos da nuvem. A sua nuvem particular impede e dificulta o seu encontro com o self. A nuvem está revestida de diversos aspectos simbólicos que revelam uma natureza confusa, indefinida, indiferenciada, metamórfica; "o nevoeiro também simboliza a indeterminação de uma fase de evolução: quando as formas não se distinguem ainda, ou quando as formas antigas que estão desaparecendo ainda não foram substituídas por novas formas precisas" (CHEVALIER e GHERBRANDT, 2012, p. 634). Devido a essa sua natureza de impermanência, a nuvem também pode representar desapego, no caso de Bastiana Africana, um desapego ao que ela acredita precisar deixar de ser para ir ao encontro do vir a ser, um processo de transição iniciática em que é preciso ultrapassar uma espécie de "prova do nevoeiro". Mas a sua nuvem é clara, cheia de luminosidade e isso é um sinal positivo, porque logo se dissipará. A festa junina parece ter ajudado essa estudante a ultrapassar esse caminho nebuloso, através do movimento, da dança, do teatro, das histórias contadas, do encontro com os colegas, do encontro e identificação com outras culturas, ou mesmo no encontro com aquilo que pensava ser do outro, mas também é dela.

As festas juninas ajudaram Bastiana Africana em seu processo de Individuação e isto a faz querer prosseguir caminho adentro sem ter certeza do que está a sua frente, mas segue confiante porque se sente segura dentro da escola. Para fortalecer o que nos apresentou na narrativa sobre a festa Junina, ela nos apresentou a tela IDENTIDADE ${ }^{\text {ix }}$, que, segundo sua inspiração, simboliza os sentimentos que essa festa lhe provocou.

A festa junina desperta esses sentimentos em Bastiana Africana na forma como se apresentam para ela como a oportunidade de se fazer em curvas, porque as curvas possibilitam olhar a vida por ângulos diferentes, e este movimento a direciona para a busca por identidades. A curva provoca soltura. Seja nas curvas das coreografias do seu corpo ou na forma circular Revista Interinstitucional Artes de Educar. Rio de Janeiro, V. 7, N. 1 - pág. 151-170 janeiroabril de 2021: "Pedagogias Vitais: Corpo, Desejo e Educação" DOI: 10.12957/ riae.2021.54782 


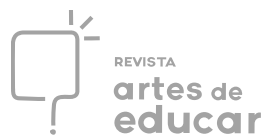

em que o espaço cênico é montado, seja mesmo no retorno às origens, à matriz da formação da alma brasileira que é evocada nos rituais dançantes das apresentações artísticas dos alunos e dos professores - como o carimbó, o maracatu, o coco, as danças em círculo, o maculelê ou mesmo as chamadas de santo, como na roda para Xangô, São João e Adonis, como ocorrido na festa FOGO EM TERRAS DE VENTO.

\section{Marco de Quitéria e seus tremores}

Marco de Quitéria é um rapaz belo, alto e simpático. Tem dezessete anos, é um menino sensível e gosta de poesia, arte, história e literatura. Chegou ao colégio universitário em 2016 para findar seus estudos na Educação Básica. Tem duas famílias, uma que chama família de consideração; outra, de sangue. Sua família de consideração é muito festeira e costuma celebrar todas as datas comemorativas do ano, a família de sangue, nem tanto. O sangue fala mais alto e ele diz não gostar muito de festa, mas mesmo assim conta, vibrante e empolgado, as sensações que teve a respeito da Festa Junina nessa escola, algo totalmente novo e emocionante. Para ele, no geral, "festa é o espaço de se sentir feliz, de se sentir bem com aquelas pessoas que você quer, comemorar, comer o que você gosta... ouvir as músicas de que você gosta e dividir com as pessoas. ",

Aluno do terceiro ano do Ensino Médio participou da festa de 2016. Na festa AMOR, ANTONIX AMOR, fez o papel do Rei do Maracatu, prólogo de abertura da festa. Conta que a música do Maracatu mexeu muito com ele e que "foi como entrar na água gelada da praia, quando se tem aquele impacto primeiro e depois você vai curtindo a onda, a primeira e a segunda... era como se a música nunca acabasse."

O entusiasmo tomou conta dele ao explicar como foi a experiência do COLUNI, porque disse que nunca havia sentido coisas parecidas numa festa, que algumas cenas ficaram gravadas em sua memória para sempre. Ele afirma que sempre participou das festas juninas nas escolas anteriores, mas que nessa, a forma como os festejos aconteciam eram bem diferentes. Nas escolas particulares em que estudou os pais tinham que comprar "de um tudo" para que o filho pudesse participar da festa. As coreografias eram fragmentadas e em nenhum momento ele sentiu vontade de se aproximar dos colegas de outras turmas porque isso não era incentivado. Por essa razão não se sentia muito estimulado a participar daquelas festas, senão por obrigação. No entanto, agora nessa nova escola, achou tudo "diferente, vibrante, emocionante, cativante" e sentia-se instigado a entrar na festa. 
Nessa mesma festa, participou também do Carimbó, coreografia que a sua turma se envolveu com muita força de vontade. Para a turma, essa foi a última dança, foi como uma despedida do colégio; para ele foi a primeira e a última, igualmente importantes porque despertou muitas imagens na sua mente, principalmente por causa do que se apresentava nas coreografias. E lembra dos momentos mais marcantes dessa festa. Um deles foi ver um colega segurando o estandarte do Maracatu. Ele descreve a cena assim:

Vi Pedro Nhatchengo segurando o Santo Antônio na dança do Maracatu. Ele estava na minha frente, ele estava por trás do estandarte, mas eu o via porque estava perto, e ele sorria, o seu corpo e seu rosto sorriam, eu vi o que ninguém viu. Todo mundo via somente o pezinho dele, e eu via o rosto dele, o movimento dele, eu via o que todo mundo via e todo mundo que estava lá sabia que ele estava assim também. As pessoas viam somente o pé dele, mas sabiam que ele deveria estar sorrindo, deveria estar feliz, ele não estava ali à toa.

Marco de Quitéria contou-me que a experiência com os movimentos circulares do carimbó foi muito forte e despertou nele sensações diversas. Segundo ele,

[...] a costura desenhada na coreografia o deixava quase tonto, que provocava um entrelace contínuo entre as pessoas; por isso, diz que a dança do carimbó, toda ela feita em roda, e nessa roda as pessoas circulavam, via-se todo mundo e quando rodava via-se tudo, via-se todo o colégio ali, uma roda dentro da roda.

Experimentar no corpo o ritmo do carimbó fez esse jovem perceber a intensidade que o movimento provoca nas pessoas e de como ele pode ser carregado de sentidos e significados. Assim, comenta:

Não foi só dançar, foi a oportunidade de representar uma cultura, representar uma música, e você dançar e cantar uma música e fazer gestos e bater palmas e reverenciar e chamar as pessoas para sentir o que você está sentindo é uma coisa muito forte. Um sentimento em comum. E você vê que todo mundo tem o mesmo sentimento, sente uma coisa boa, em intensidades diferentes, mas sente.

Repetidas vezes, durante a festa, pronunciou a frase “como estou feliz! Sentia uma coisa pulando”, um saltitar interno que o fez "querer abraçar as pessoas, os amigos, as mães dos amigos, os desconhecidos presentes". E, assim, conta: "Eu vi a mãe de um amigo meu dançando, eu vi minha mãe dançando, e na hora de abrir a roda tudo era muito lindo, daí o abraço foi quase que sem se perceber, foi instantâneo e espontâneo”. Quando diz isso, referese à quadrilha que acontece no final das festas em que, como vem acontecendo todos os anos, Revista Interinstitucional Artes de Educar. Rio de Janeiro, V. 7, N. 1 - pág. 151-170 janeiroabril de 2021: "Pedagogias Vitais: Corpo, Desejo e Educação" DOI: 10.12957/riae.2021.54782 


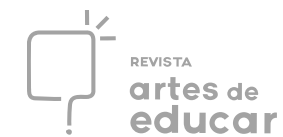

as famílias invadem a quadra e dançam com os alunos e os professores. Enquanto relatava os seus sentimentos, Marco de Quitéria vibrava, suas mãos tremiam, parecia que seu corpo queria dançar naquele momento.

Disse ainda que é importante a forma como as questões culturais do Nordeste são trabalhadas durante a festa, porque, "em primeiro plano, promove o respeito e a admiração dos alunos pela cultura popular nordestina, eliminando preconceitos", e em segundo plano as questões do sofrimento ou as agonias do nordestinos em tempos de seca ou de pobreza são apresentadas junto à alegria e ao bom-humor costumeiramente presentes na vida desse povo. E isto enriquece muito o que é contado e como é contado durante a festa.

Marco de Quitéria disse ter percebido que as pessoas não vêm para a "festa junina do COLUNI somente para dançar e comer, mas para estudar, aprender, viver!. E destacou o seguinte: "você faz a festa junina em qualquer lugar, mas aqui no COLUNI dá-se sentido a ela”. Para ele, "isso é muito legal, transforma o aprendizado em conhecimento”.

Por falar em conhecimento e levando isso para as questões de formação, esse jovem estudante entende que a festa Junina que acontece nessa escola forma as pessoas como seres humanos, sem perder de vista os estudos para que o tema seja desenvolvido e apresentado. Daí ele dizer que isso torna as coisas mais fáceis, "porque todo mundo teve que estudar para aquilo acontecer, teve que trabalhar para a festa acontecer", que todos ficam sabendo do que "fala a festa, sabem qual a roupa mais adequada, sabem o que as músicas falam”. E faz questão de contar, para exemplificar, como adquiriu conhecimentos na festa a partir de sua ida à exposição Casa Brasil, na ocasião das Olimpíadas de 2016, em que ficou surpreso ao visitar o setor dedicado às festas juninas porque, naturalmente, reconheceu todos os elementos cenográficos expostos sem precisar de legendas. Sobre isso disse: "Eu não sabia o nome daquela fivela do cavalo, mas eu tinha familiaridade com aquilo”. Fecha com o seguinte comentário:

Eu sei hoje qual é a comida, eu sei qual é a roupa, eu sei como as pessoas se sentem nessa época do ano por causa do que vivemos aqui na escola. A satisfação acadêmica gera a satisfação pessoal. Será que o fato de uma pessoa ter preconceito com nordestino não é ignorância? Será que se ele aprendesse como nós aprendemos nessa festa junina não seria diferente? Você evolui quando interage com as pessoas.

Para Marco de Quitéria, a melhor imagem ${ }^{\mathrm{x}}$ que descreve a Festa Junina do COLUNI, a partir do que vivenciou em AMOR, ANTONIX AMOR, é o pôr do sol. "Aquele bem alaranjado, que acaba bem rápido. Aquele que você não esquece nunca”. 
A imagem mencionada acima surgiu também em conversas com outros participantes da festa. O por do sol é o momento em que o dia, em seus raios cintilantes solares, encontra a escuridão da noite e a luz cristalina da lua. Nas imagens do poeta Gaston Bachelard, na obra "Dicionário de imagens, símbolos, mitos, termos e conceitos Bachelardianos", "o sol poente é uma forja que se estende ao plano cósmico" (ALVAREZ 2013, p.87) em seus tons de vermelho e amarelo que alaranjam o azul celeste. As cores que saem do ferro forjado simbolizam valor, força e energia, assim é o por do sol de Marco de Quitéria. A imagem do sol poente tem muita força e pode significar a forja no plano cósmico, como nos explica Gaston Bachelard,

Realmente, o sol poente é uma imagem de nirvana, uma imagem de paz, de aquiescência à vida noturna e como tal essa imagem do sol se espalhando, se alargando, do sol associando o universo ao seu repouso, domina um grande setor do devaneio da noite... O sonhador, entregue a seu sonho cósmico, termina o dia tomando consciência de sua força que domina o universo. Mesmo quando o forjador parece ausente, só pelo fato de a imaginação pôr o sol sobre a bigorna, uma impressão de força invade o poeta. $\mathrm{O}$ sol fica então vigoroso, vigoroso em seu poente. (idem, p. 164)

Como um ferreiro que coloca na forja o dia e se deleita com a noite, Marco de Quitéria participou das festas juninas intensamente. No final, seu fim da noite foi êxtase da experiência vivida que lhe trouxe, em corpo exaurido e alma alimentada, diversos sentimentos. Ele diz: “ $E u$ sai muito feliz, sai extasiado. Quando sentei no carro voltando pra casa disse assim... Estou muito feliz!"

\section{E a Festa continua viva em nossos corpos}

A festa provoca, atiça esse sentir, comove e traz o sentimento de pertença, o que gera um estado de felicidade. Nesse cenário, então, é importante destacar que, via narrativas, os entrevistados viram nessa experiência que o importante era o contato, o sentir junto, o estar junto, os corpos juntos, o que favoreceu, para eles, a mudança de atitudes, as formas de trabalhar em grupo, de se organizarem em grupo, imbuídos de razão e de poesia. Destacaram, também, um importante alicerce das relações na escola: o acolhimento - que promove a aproximação dos diferentes, sem hierarquizações. Na percepção desses jovens, a festa, as festas, desencorajam a atitude preconceituosa, envolta de racionalização. 
Acreditamos que a festa pode mobilizar o que há de humano no homem, resgatando a sua humanidade, tão cara na contemporaneidade. E, para tal, é preciso, no sentido de exato e no sentido de necessário, entrelaçar o poético e o prosaico.

O poema José, de Carlos Drumond de Andrade (ANDRADE,1993, p.35) cai muito bem aqui.

$$
\begin{aligned}
& \text { E agora, José? } \\
& \text { A festa acabou, } \\
& \text { a luz apagou, } \\
& \text { o povo sumiu, } \\
& \text { a noite esfriou, } \\
& \text { e agora, José? }
\end{aligned}
$$

Pensamos e torcemos, veementemente, para a busca e o encontro de caminhos a serem construídos para a mudança da condição de limitação e alienação corporal que se impõe por um sistema social mecanicista, racional e insensível, que se arrasta há séculos nas instituições escolares. Buscamos e acreditamos em uma educação mais sensível.

\section{REFERENCIAS}

ALVAREZ Ferreira, Agripina Encarnacion. Dicionário de imagens, símbolos, mitos, termos e conceitos Bachelardianos. Londrina : Eduel, 2013.

ANDRADE, Carlos Drummond de. José/ Novos Poemas/ Fazendeiro do ar. Rio de Janeiro: Record, 1993.

BACHELARD, Gaston. A poética do devaneio. São Paulo: Martins Fontes, 1988.

O ar e os sonhos. São Paulo: Martins Fontes, 1990.

CHAVES, Iduina. (org.). Formação de professores: educação, cultura e imaginário. Niterói: Intertexto, 2006.

A pesquisa narrativa: uma forma de evocar imagens da vida de professores. In: Imagens da cultura: um outro olhar. São Paulo: CICE/FEUSP, 1999

CHEVALIER, Jean; GHERBRANDT, Alain. Dicionário de Símbolos: mitos, sonhos, costumes gestos, formas, figuras, cores, números. Rio de Janeiro: José Olympo, 2012.

DELORY-MOMBERGER, Cristine Abordagens metodológicas na pesquisa biográfica. Revista Brasileira de Educação v. 17, n. 51, p.523-536, set.-dez., 2012. 
DURAND, Gilbert. As estruturas antropológicas do imaginário. Trad. De Helder Godinho. São Paulo: Martins Fontes, 2001.

A Imaginação simbólica. São Paulo: Cultrix, 1988.

DUVIGNAUD, Jean. Festas e Civilizações. Rio de Janeiro: Tempo Brasileiro, 1985.

GONÇALVES, Maria Augusta Salin. Sentir, pensar, agir: corporeidade e educação. São Paulo: Papirus, 2008

HUIZINGA, Johan. Homo ludens: o jogo como elemento da cultura. São Paulo: Perspectiva, 2004.

KELEMAN, Stanley. Mito e corpo: uma conversa com Joseph Campbell. Tradução de Denise Maria Bolanho. 3. ed. São Paulo: Summus, 2001.

LE BRETON, David. As paixões ordinárias: antropologia das emoções. Petrópolis: Vozes, 2009.

A sociologia do corpo. Petrópolis, RJ: Vozes, 2007

MAFFESOLI, Michel. Saturação. São Paulo: Iluminuras, 2011.

. No fundo das aparências. 4ed. Petrópolis, RJ: Vozes, 2010.

. O tempo das tribos: o declínio do individualismo nas sociedades de massa. Rio de

Janeiro: Forense - Universitária, 2000.

MORIN, Edgar. Amor, poesia, sabedoria. 10 ed. Rio de Janeiro: Bertrand Brasil, 2011.

(org). Educar na era planetária: o pensamento complexo como método de aprendizagem no erro e na incerteza humana. São Paulo: Cortez, 2003.

. Meus demônios. 6 ed. Rio de Janeiro: Bertrand Brasil, 2000a.

. Os sete saberes necessários à educação do futuro. Tradução de Catarina Eleonora F. da Silva e Jeanne Sawaya . Revisão técnica de Edgard de Assis Carvalho. - 2. ed. - São Paulo: Cortez; Brasília, DF : UNESCO, 2000b.

SHAW, Harry. Dicionário de termos literários. Lisboa: Dom Quixote, 1982

SERRES, Michel. Variações sobre o corpo. Rio de Janeiro: Bertrand Brasil, 2004.

\footnotetext{
${ }^{\text {i }}$ Professor do quadro efetivo do Colégio Universitário Geraldo Reis - COLUNI/UFF. Doutor em educação pela Universidade Federal Fluminense (UFF), Mestre em Artes Cênicas pela UNIRIO, tem Licenciatura em Artes Cênicas (UNIRIO) e Educação Física (UESPI). Membro pesquisador do Grupo de Pesquisa Cultura, Imaginário, Memória, Narrativa e Educação (CIMNE/UFF/CNPq). ORCID iD https://orcid.org/0000-0002-5407-8116.

ii Possui graduação em Pedagogia pela Universidade Estadual do Ceará (1975) e doutorado em Educação pela Universidade de São Paulo (1998). Atualmente é Professor Adjunta da Universidade Federal Fluminense. Tem experiência na área de Educação, com ênfase em Ensino-Aprendizagem. Atuando principalmente nos seguintes 
temas: Cultura Organização Imaginário sócio antropologia. Universidade Federal Fluminense (UFF). Niterói/Brasil. ORCID iD http://orcid.org/0000-0003-4732-8436.

iii Professora Associada da Faculdade de Formação de Professores da UERJ; Doutora e Mestre em Educação- UFF; Graduada em Educação Física- UGF; Coordenadora do Projeto de Extensão ECOAR (FFP/UERJ)- Educação, Corporeidade e Artes. Membro dos Grupo de Pesquisa: CIMNE (UFF) Cultura, Imaginário, Memória, Narrativa e Educação; Formação de Professores, processos e práticas pedagógicas ( FFP/UERJ); Grupo de Pesquisa Corporeidade e Ludicidade- GEPECOL (UFMT). Universidade do Estado do Rio de Janeiro (UERJ). Rio de Janeiro/RJ. ORCID iD https://orcid.org/0000-0002-2324-1953.

iv As festas Juninas do COLUNI abordam temas relacionados à Cultura popular. São desenvolvidas a partir de enredos criados pelos docentes e construídos com toda a comunidade ao longo do processo. A área de Arte, Corpo e Cultuara da Escola, composta por docentes de Artes Visuais, Artes Cênicas, Música e Educação Física, é a responsável pela condução desse projeto que liga os segmentos do Ensino Fundamental I, Ensino Fundamental II e Ensino Médio. Assim, estudantes, professores, estagiários, funcionários e responsáveis têm voz durante todo o processo. A culminância do projeto se dá nas apresentações cênicas de teatro, música e de dança que acontecem na quadra da escola em período junino.

${ }^{v}$ A noção de socialidade, cunhada por Michel Maffesoli (2000), se refere ao relativismo do viver, sobretudo na Pós-modernidade, visto que a sociabilidade da era Moderna, vinculada às ideias de Liberdade, Igualdade e Fraternidade (marcas do Iluminismo) vai dando lugar a um sentimento mais imediatista, à fragmentação das certezas, à busca pelo outro, pelo desejo de viver-junto-com, caracterizando uma nova forma de viver em sociedade.

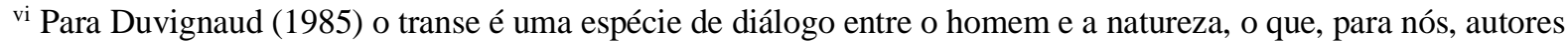
desse texto, inclui a sua própria natureza emocional e corpórea.

vii As capulanas consistem em tecidos que são, tradicionalmente, usados por mulheres moçambicanas para envolver os seus corpos. São usados na cabeça como uma espécie de turbantes, como saias, como blusas ou para carregar os filhos em suas costas. São também usadas como toalhas de mesa, cortina e até tapetes quando se quer homenagear alguém especial que se chegue à casa. As mulheres mais velhas costumam guardar suas capulanas em baús e entregam às filhas em época de casamento ou situações especiais. É um pedaço de tecido carregado de histórias, e que também conta a histórias do povo Moçambicano. São extremamente simbólicos. Seu uso se dá desde muito tempo e ainda perdura até hoje. Pelas ruas de Moçambique é costumeiro ver várias bancas de venda destes tecidos estampados coloridos e muitas mulheres moçambicanas trazendo capulanas em seus corpos. De costume os homens moçambicanos usam capulanas somente em camisas de alfaiataria, como detalhes em mangas, punhos ou golas.

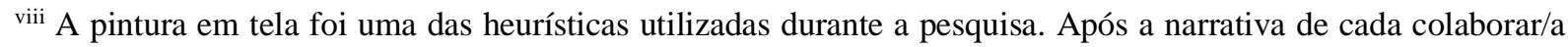
ele/ela foi convidado/a a pintar uma tela que representasse, simbolicamente, a festa junina.

ix No caso da Bastiana Africana, sua tela apresenta três faixas horizontais coloridas esfumadas. De cima para baixo temos as cores azul, em que se vê a palavra "identidade"; a cor laranja em que se vê um "coração encarnado"; a cor verde em que se vê a palavra "ser"; e, por fim, um tom de rosa em que Bastiana apresenta o símbolo de uma interrogação.

${ }^{x}$ Outra Heurística utilizada na pesquisa foi a imagem simbólica afetiva que se forma em pensamento. Os(as) colaboradores(as) disseram que imagem surgia, em seus pensamentos e que representasse o sentimento que ele(ela) tinha a respeito da Festa Junina do COLUNI. No caso de Marco de Quitéria, ele nos traz o "pôr do sol". 